\title{
Rafał Zarębski
}

DOI: 10.33896/PorJ.2020.1.6

(Uniwersytet Łódzki,

e-mail: rafal.zarebski@uni.lodz.pl)

ORCID: 0000-0003-1918-2169

\section{NAZWY CZARNOSKÓRYCH MIESZKAŃCÓW AFRYKI W DAWNYCH PRZEKLADACH NOWEGO TESTAMENTU}

Do przyjrzenia się określeniom wskazującym na czarnoskórych mieszkańców Afryki w średniopolskich przekładach Nowego Testamentu (NT) skłoniły mnie problemy, które obserwujemy we współczesnej polszczyźnie. Okazuje się bowiem, że niełatwo dziś znaleźć nazwę dla osoby czarnoskórej, która byłaby jednoznaczna, syntetyczna, a przede wszystkim pozbawiona ocen wartościujących. Ogląd słowników dokumentujących leksykę współczesna, publikacji o charakterze poprawnościowym, a także wypowiedzi użytkowników języka zamieszczanych w mediach dowodzi, że trudno wskazać taka jednostkę leksykalna, która trafnie oddawałaby sens grupy nominalnej osoba czarnoskóra // ciemnoskóra.

Na wskazany problem warto spojrzeć $z$ szerszej perspektywy, w której można by się odwołać do faktów historycznych. Interesująca wydaje się próba dotarcia do źródeł powstania negatywnych skojarzeń, w jakie obrosły nominacje odnoszace się do osób czarnoskórych, oraz wskazania przyczyn, zarówno językowych, jak i pozajęzykowych, które spowodowały, że pewne leksemy nabrały zabarwienia ujemnego. Asumptem do przedstawianych tu rozważań stały się dwa krótkie fragmenty z polskich przekładów Dziejów Apostolskich, stanowiących część NT, w których pojawiły się rozmaite ekwiwalenty tłumaczeniowe odnoszace się do osób o czarnej skórze. Celem opracowania jest prześledzenie tendencji translatorskich w zakresie wykorzystywania polskich lub mających obca proweniencję, ale przyswojonych, odpowiedników leksemów greckich (użytych w wersji oryginalnej NT) i łacińskich (wykorzystanych w Wulgacie), uwzględniające analizę semantyczną tych nazw $z$ odwołaniem się do danych leksykograficznych, a w mniejszym zakresie także tekstowych oraz do uwarunkowań pragmalingwistycznych. Prowadzone w ten sposób obserwacje powinny pomóc nie tylko we wskazaniu zależności pomiędzy zmianami semantyki interesujacych mnie określeń w polszczyźnie ogólnej na poszczególnych etapach jej historii a indywidualnymi wyborami tłumaczy, ale również w uchwyceniu momentu, w którym dana, pierwotnie neutralna, nominacja uzyskała ujemny odcień znaczeniowy. 
Analiza filologiczna objęto jednostki wyekscerpowane z 10 polskich przekładów biblijnych, powstałych w XVI i XVII w., opartych na różnych podstawach (greckim oryginale: NTM, BBrz, BB, NTB, NTCz, BG, łacińskiej Wulgacie: NTSz, BL, NTW, BW), zróżnicowanych nie tylko wyznaniowo (przekłady protestanckie, katolickie, ekumeniczne itd.), ale także w zakresie technik i strategii tłumaczenia. ${ }^{1}$

W Dziejach Apostolskich leksemy odnoszące się do postaci pochodzących $z$ Afryki, najprawdopodobniej, jak o tym przekonuja znawcy przedmiotu, czarnoskórych, wystąpiły trzykrotnie w obrębie dwóch wersetów [Ia, Ib, IIa]:

I.

A on poszedł. Właśnie wtedy przybył do Jerozolimy oddać pokłon Bogu [Ia] Etiop, dworski urzędnik (Ib) królowej etiopskiej, Kandake, zarza-

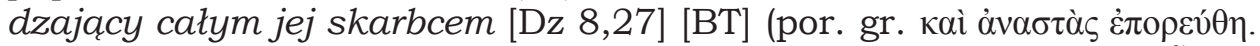

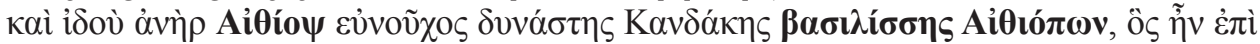

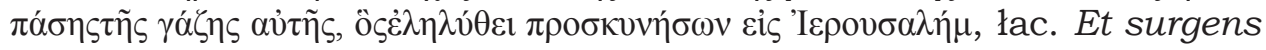
abiit; et ecce vir Aethiops eunuchus potens Candacis reginae Aethiopum, qui erat super omnem gazam eius, qui venerat adorare in Ierusalem);

II.

W Antiochii, $w$ tamtejszym Kościele, byli prorokami i nauczycielami: Barnaba i Szymon zwany [IIa] Niger, Lucjusz Cyrenejczyk i Manaen, który wychowywat sie razem $z$ Herodem tetrarcha, $i$ Szawet [Dz 13,1] [BT]

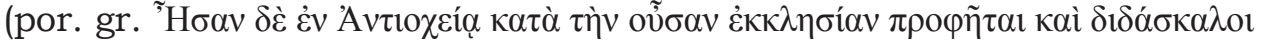

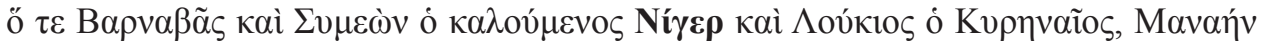

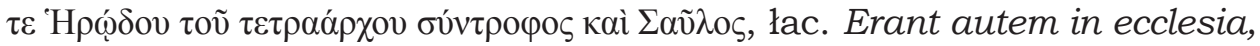
quae erat Antiochiae, prophetae et doctores: Barnabas et Simon, qui vocabatur Niger, et Lucius Cyrenensis, et Manaen, qui erat Herodis tetrarchae collectaneus, et Saulus). ${ }^{2}$

Informacji na temat wspomnianych osób dostarcza m.in. konkordancja Cz. Bosaka [1996, 123, 432, 659], w której możemy przeczytać, że: Etiop(czyk) (gr. Aithiops 'człowiek o opalonym obliczu', od gr. aito 'palić'), mieszkaniec Etiopii (hebr. Kusz 'ten ze spalona [słońcem] twarza'); człowiek, o którym mowa w Dz 8,26-39), to najprawdopodobniej Żyd (od VII w. p. Chr. w Etiopii żyło wielu Żydów), dworski urzędnik królowej, zarządca jej skarbca, który nawrócony przez Filipa, diakona, w drodze z Jerozolimy do Gazy i przez niego ochrzczony (być może przy źródle w dzisiejszym Ain-Dirne, $7 \mathrm{~km}$ od Hebronu); 3

1 Na temat przekładów wykorzystanych do badań zob. m.in. Kossowska 1968; Pietkiewicz 2016.

2 Tekst grecki i łaciński za: NA. Skróty tytułów ksiag biblijnych za BT.

3 W legendach śródziemnomorskich i geografii mitologicznej Etiopię utożsamiano z krańcem Ziemi, a najczęściej wymienianą cechą Etiopczyków w litera- 
Kandake (gr. Kandake) to imię dynastyczne władców królestwa Nubii lub Etiopii (Etiopią albo Nubia nazywano wszystkie królestwa położone na południe od Egiptu). Kraj ten był rządzony przez dynastię dziedziczna w linii żeńskiej, przy tym każdą królową nazywano Kandake, podobnie jak władcę Egiptu - faraonem, a władcę Rzymu - cesarzem;

Szymon, zwany Niger (hebr. Shimeon, Shimon lub Szemael 'Bóg mnie wysłuchał', 'wysłuchanie', gr. Symeon, Simon 'człowiek płaskonosy', gr. Niger 'czarny'), był jednym z pięciu „proroków i nauczycieli” Kościoła antiocheńskiego. Nie jest wykluczone, że łaciński przydomek Niger został mu nadany ze względu na kolor skóry, co wskazywałoby na jego południowe, a może nawet afrykańskie pochodzenie.

W przekładach XVI- i XVII-wiecznych mamy do czynienia $z$ następującymi ekwiwalentami: ${ }^{4}$

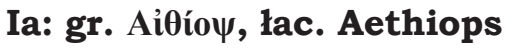

1. Murzyn rzezaniec [BL], maż murzyn rzezaniec [NTSz, BB, NTB, BG],

2. Etyopczyk rzezaniec [NTCz], Etyopczyk *w greckim stoi Eunuchus co sie właśnie rozumie rzezaniec [BBrz], Aethyopianin [NTW], maż Aethyopianin rzezaniec [BW],

3. Murzyn podkomorzy *masz Ethyopczyk rzezaniec [NTM];

\section{Ib: gr. $\beta \alpha \sigma \imath \lambda i ́ \sigma \sigma \alpha A i \theta t o ́ \pi \omega v$, lac. regina Aethiopum}

1. Krolowa Murzyńska [NTM, NTSz, BL, BB, NTB, BG],

2. Krolowa Aethiopska [NTW], Krolowa Etyopska "tym imieniem pospolicie nazywaia wszytki Krolowe Etyopskie [BBrz], Krolowa Etyopska [NTCz], Krolowa Aethyopska [BW];

\section{IIa: gr. Níyep, lac. Niger}

1. Simon który przeziwan był czarny [NTSz], Symon ktorego przezywano czarnym [BL], Symon ktorego zwano Czarny [BBrz],

2. Symeon ktorego zwano Nigrem [NTCz], Symon [Symeon] ktorego zwano Nigrem [NTW], Symon nazywany Niger [BB], Symon ktorego zwano Niger [BW, BG],

3. Simon przezwiskiem Niger *ktorego zowia czarny [NTM], Symon nazwany Niger *to iest czarny [NTB].

Z obserwacji materiału średniopolskiego można wyciagnać następujące wnioski. Formy Etyjopczyk, Etyjopianin i derywat przymiotnikowy etyjopski wystapiły w przekładach ks. J. Wujka [NTW, BW], korzysta-

turze żydowskiej i grecko-rzymskiej [też w Starym Testamencie Jr 13,23] była ich ciemna skóra [zob. Keener 2000, 255].

4 Pełne zestawienie wszystkich ekwiwalentów zob. Aneks. Materiał przytaczam w transliteracji, a fragmenty poprzedzone asteryskiem pochodza $z$ glos marginesowych w poszczególnych przekładach. 
jacego $z$ Wulgaty oraz tłumaczonych $z$ greki NTCz i BBrz, a w wypadku NTM - w glosie marginesowej. Podobnie leksemy Murzyn // murzyn i murzyński pojawiły się $\mathrm{w}$ dawnych tłumaczeniach, zarówno opartych na greckim oryginale [teksty Szymona Budnego - BB i NTB oraz BG], jak i na Wulgacie [NTSz, BL]. Obie formy wykorzystał autor innowierczego przekładu NTM, przy czym w tekście głównym zastosował rzeczownik Murzyn, etnonim Etyjopczyk wysuną na margines. Żaden $z$ autorów nawróconego Etiopczyka ani etiopskiej królowej nie określił przy użyciu substantywizowanego przymiotnika czarny, czarna. Warto odnotować konsekwencję tłumaczy okresu średniopolskiego, polegająca na unikaniu różnych form w bliskim sąsiedztwie. Jeśli więc ktoś zdecydował się na użycie rzeczownika Murzyn, to również królową Kandake określił pochodnym od niego przymiotnikiem. Analogicznie rzecz wygląda w odniesieniu do drugiego $z$ wykorzystanych w obrębie przywołanej tu lokalizacji gniazda słowotwórczego.

Oboczność Murzyn // Etiop(czyk) w ekscerpowanych przekładach ma głębsze źródło. Hebrajczycy Etiopię nazywali Kûš, a jej mieszkańca od koloru skóry - kûuši 'czarny' (pl. kûšîm). ${ }^{5} \mathrm{~W}$ Septuagincie nazwę tego kraju oddano jako Aithiopia, a jej mieszkańca określono mianem Aithiops. Formy te przejęła Wulgata. Z badań I. Kwileckiej [2001] wynika, że w dawnych przekładach Biblii na języki narodowe (m.in. polski, czeski, francuski) jedni tłumacze, nawiązując do tekstu hebrajskiego, tłumaczyli za pomoca leksemu wskazującego na barwę czarna, inni adaptowali grecką i łacińską formę Aithiops, a jeszcze inni translokowali nazwę hebrajska - Kuszyta.

W wypadku przydomka, przezwiska Szymona dominuje tendencja do wykorzystania translokowanej formy obcej Niger. Rodzimy przymiotnik czarny został wykorzystany wyłącznie w trzech przekładach (dwóch opierających się na Wulgacie - NTSz i BL oraz jednym opartym na tekście greckim - BBrz). W dwóch tłumaczeniach (NTM, NTB) leksem czarny pojawił się jako glosa marginesowa objaśniająca użytą w tekście głównym formę obca. Jednak żaden $z$ tłumaczy nie zdecydował się określić rzeczonego Szymona za pomoca nominacji Murzyn. I w tym wypadku trudno wskazać jakieś zależności, które wynikałyby ze strategii translatorskiej, $z$ przekonań ideowych autorów czy z podstawy tłumaczenia. Obie formy wystapiły bowiem zarówno w tekstach opartych na Wulgacie, jak i na oryginale.

Na wybrane przez dawnych tłumaczy nominacje spójrzmy przez pryzmat ustaleń leksykograficznych. W tym celu odwołamy się do słowników etymologicznych oraz historycznych, które dokumentuja nie tylko

5 Nazwy Etiop (wraz z wariantami słowotwórczymi) i Murzyn pojawiaja się także w Księdze Jeremiasza w Starym Testamencie; por. Jr 13,23. 
leksykę średniopolska, ale także późniejszą (ale nie współczesna). ${ }^{6}$ Pozwoli to ukazać zarys podstawowych zmian w semantyce interesujacych nas leksemów na przestrzeni dziejów polszczyzny. W konsekwencji uzyskamy istotny kontekst dla translatorskich wyborów, które obserwujemy we współczesnych przekładach NT.

Rzeczownik Murzyn 'człowiek należący do rasy czarnej' to według Wiesława Borysia książkowe zapożyczenie ze stcz. Muřin // múřěnín 'ts.', por. cz. przest. mourenin' ts.', słc. przest. murin 'ts.', co przejęte $z$ łac. Maurus 'Maur, północnoafrykański murzyn', które pojawiło się w polszczyźnie dla potrzeb przekładu Biblii [SEBor]. Aleksander Brückner leksem ten wywodzi $z$ niem. Mohr, to zaś $z$ łac. maurus 'czarny' [SEBr], a Andrzej Bańkowski przypuszcza, że może to być zapożyczenie wędrowne $z$ języka staro-cerkiewno-słowiańskiego, „gdzie powstało jako typowo przekładowe słowo biblijne (= gr. Aitiips, adi. Aiti-ops -opos 'ciemnolicy, o ogorzałej od słońca twarzy', por. gr. aitós 'ogorzały', aitálē, aithalos 'sadza' itp.; od sb. †murb -i f 'ciemność, coś ciemnego', collect. 'ludzie ciemnoskórzy', od adi. †murb // †xmurb // †smurb 'ciemny')" [SEBań].

W Sstp konteksty wyekscerpowane $z$ ówczesnych przekładów Biblii (Psałterza floriańskiego, puławskiego i Biblii szaroszpatackiej) potwierdzają ograniczony ówcześnie zasięg stylistyczny leksemu Murzyn 'ciemnoskóry mieszkaniec Afryki, Aethiops', np. „Przydø poslowe z Egipta, murzinowe przeidø røky iego bogu (Aethiopia praeveniet manus eius deo)” [Fl 67,34], [sim Pul]; „Moszely mvrzyn (Aethiops) przemyenycz scorø swø" [BZ Jer 13,23]. Wyłącznie w stylu biblijnym funkcjonował wtedy również derywat przymiotnikowy murzyński 'związany z ciemnoskórymi mieszkańcami Afryki, Aethiopicus' [Stp.].

Poza literaturę biblijna jednostka Murzyn i jej derywaty (Murzynka, adi. murzyni, murzyński) wychodza w polszczyźnie renesansowej. SXVI notuje interesujący nas rzeczownik przede wszystkim jako nazwę etniczną 'człowiek o ciemnej skórze, mieszkaniec Afryki, zwłaszcza Abisyńczyk lub Maur', ${ }^{7}$ obecną w różnych typach tekstów (zarówno religijnych, jak i świeckich), np. „która też [cholera] w ciepleyszych krainach cżyni włosi twarde, iako sa v murzinow” [GlabGad A8v]; „wspomnićietesz sobie / / iáko Filip Apostoł swięty / onego Murzyná starostę Krolowey Kándáces okrzćił?” [KrowObr 83v]; „Przestrássył Pan Bog ony Murzyny [Aethiope; AEthopiány WujBib] przed Asa”" [Leop. 2.Par 14/12, 2 Par 14 arg, 12 [2 r.]]. Rzeczownik ten wchodził wówczas w skład szeregów synonimicznych typu Murzyn, (abo) Cygan(in), czarni ludzie abo Murzynowie, Etyjop to jest Murzyn, Maurowie albo Murzynowie, Nigryta to jest Murzyn.

6 Na temat semantyki ekwiwalentów należacych do pola <osoba rasy czarnej> w przekładach współczesnych zob. Zarębski - w druku.

7 Por. znaczenie 2. 'chrześcijanin kościoła etiopskiego w obrządku koptyjskim' i 3. n. loci 'Etiopia': „Etiopya tho iest Murzyny” [BielKron 270v] [SXVI]. 
Warto zwrócić uwagę na przysłowia oparte na porównaniu z członem murzyn, w których można by się dopatrywać żartobliwych, a w związku $z$ tym pewnie ujemnych sensów, np. „A ták to iest trudna / iako Murzynowi omyć czarność swoię" [CzechRozm 34v, ModrzBaz12] (też wyrażenia czarny (być) jako (a. by) Murzyn, goracy [= zamieszkujacy ciepłe kraje] Murzyn, Murzyn słoncem przypalony, zafarbowany) oraz znaczenia metaforyczne 'czarny, odrażający stwór; wyobrażenie diabła', np. czarni murzynowie straszliwi z pism P. Skargi.

Wiele poświadczeń użycia leksemu murzyn znajdziemy w kartotece SXVII/XVIII, np. „Rzymianie / nigdy wszystkiey Afryki / nigdy wszytkiey Azyiey podbić nie mogli / nigdy do Murzynow ábo Abyssinow nie zachodzili" [Birk.Niedz. 1623, s. 145], przy czym sporo kontekstów zawiera element wartościujaccy negatywnie, np. „Murzyna myć o rzeczy niepodobney y ná którą się dawno i próżno sadzić” [Dan. Dict. II, 244], „Znamię Krzyżáa Ś. ná czele swym połozył / y zaraz tym obrzydłych onych Murzynow hufy rospędził” [At.Kaln. Cuda Kijów 1638, s. 3], "Tedy mu się pokaże raz Murzynem brudnym, / Drugi mu raz się stawi harcerzem obłudnym" [M.Kulig.Król. 1638, 278]; „szpetna Murzynka” [MikućSilva 1733, 233]. Warto dodać, że w piśmiennictwie $z$ tego czasu (m.in. w Pieśni o zajączku Hiacynta Przetockiego czy XVIII-wiecznych Nowych Atenach Benedykta Chmielowskiego) odnotowano również - najprawdopodobniej ze względu na synonimiczny charakter względem leksemu czarny - jednostkę $\mathrm{Mu}$ rzyn w funkcji zoonimu, jako imię psa [Kart SXVII/XVIII].

Podobny stan można zaobserwować w materiale SL, por. konteksty neutralne, np. „Nigryczykowie abo murzyny, nazwisko, które dajemy narodom czarnym, mieszkającym w Nigrycyi, Gwinei, Abissynii i innych pogranicznych krajach” [Dyk.G.2, 218], „powszechnie tak [Murzynami R.Z.] nazywamy ludzi czarnych, $z$ krajów południowych pochodzacych" [Kras. Zb.2,210], „Etyjopy my pospolicie murzyny nazwiem” [Budn. 1 Chron.] i użycia żartobliwe, odsyłające do czarnego (ciemnego) koloru skóry Murzynów, np. „Murzyna trudno obmywać” [Sk.Dz.558], „Często gniew ich hamował sam ociec chudzina, Nic nie wskórał, tak właśnie, jakby mył murzyna” [Zab. 16, 239], „Nie pomoże, przypowieść starodawna mówi, Czarnemu z przyrodzenia woda murzynowi” [Pot.Pocz.570], „Murzyni i murzynki, przeniesieni nawet do krajów najzimniejszych, dzieci maja czarne" [Mon.70,19] czy powszechnego wówczas traktowania przedstawicieli tej rasy jako służących, np. „Murzyn służący n.p. Co to ludzi asystować mi będzie: lokaje, strzelcy, hajduki, pajuki, murzyni, laufry" [Teat. 55].

Bez kwalifikatorów rzeczownik Murzyn (i pochodne Murzynka, Murzynek, Murzynię, murzyński, murzynów, murzyniarz 'ten, co handluje Murzynami' - SW) notuja również SWil i SW: 'człowiek czarny z południowych krajów, Negr; człowiek rasy czarnej', ale przytoczone w obu słownikach konteksty odsyłaja do raczej negatywnych aspektów zwiąanych z postrzeganiem osób czarnoskórych, np. barwa skóry: „Czarny jak Mu- 
rzyn” [SW], w tym też przede wszystkim użycia żartobliwe, np. „Próżno myjesz murzyna” [SWil], „Nie pomoże Murzynowi mydło” [SW], niewolnictwo: „Handel murzynami” [SWil], „Obchodzi się ze mna jak z Murzynem, a odstręczyć nie mogła" [Krasz.] (= jak z niewolnikiem). Sporadycznie tylko trafiają się poświadczenia z użyciami neutralnymi, np. „Z legja Dunaju tam wódz Murzyny gromi" [Mick.] [SW]. Co ciekawe, leksykony dokumentują poszerzające się stopniowo zjawisko apelatywizacji leksemu bliskiego etnonimom Murzyn, murzynek, por. bot. murzyn roślinny (łac. Aethiops vegetabilis), bot. 'pewien gatunek wodorostu' - morszczyn pęcherzykowaty, 'koń z czarnemi nogami i czarna głowa' [SWil], 'niedźwiadek' [SWil], 'gatunek jabłek' [SW], w grze w karty karc. '(w lombrze) trzynaście kart pozostałych od rozdania, stanowiących kupną' [SW], myśl. 'młody cietrzew' [SW]. SW jako pierwszy notuje przenośne wyrażenie biały murzyn 'człowiek ciężko pracujący i wyzyskiwany', nawiązujące do okresu wyzysku ludności czarnoskórej.

Jeśli zaś chodzi o leksykograficzny portret drugiego $z$ ekwiwalentów wykorzystanego przez dawnych tłumaczy w przytoczonych wyżej fragmentach NT, to warto zwrócić uwagę na następujace fakty. W Sstp jedno $z$ kilku znaczeń jednostki czarny 'niger, ater' odnosi się do ciała ludzkiego, co zostało zilustrowane cytatem z Rozmyślania przemyskiego: „Dał mi bog ociec jednego syna, a prze tego mam żałość, nędzę i wieliką tesknicę..., uczniłam się czarna i śniada, kako mogę cirpieć śmierci syna mego" [Rozm 527]. Ponadto w okresie staropolskim funkcjonowały liczne odapelatywne antroponimy: Czarny, Czerny, Czern, Czyrny, Czyrn, a także ich odpowiednik łaciński Niger i niemiecki Schwarz [SSNO]. SXVI pokazuje znacznie większy zakres łączliwości przymiotnika czarny 'mający barwę czarna lub zbliżona do czarnej; bardzo ciemny' w odniesieniu do człowieka (czarne włosy, oczy, czarna skóra). Oprócz wielu znaczeń, w tym wskazujących na czarta czy zakonników noszacych czarne habity, odnotowano wyrażenia odnoszące się do Murzyna, por. czarni ludzie „A gdy tzarne ludzi albo Murzyny we śnie widział / tzarne ssuknie i kápice Mnichom rozdał” [KrowObr 136], czarny Maur „Ċ̇ásem się puśći morzem śrzodoźiemnym (...) Do czarnych Maurow / Do Lybyiey párney" [KlonFlisDv]. Trzeba podkreślić, iż większość przywołanych kontekstów buduje negatywny stereotyp osoby czarnoskórej, por. „y vyrzy wagi / około ktorey nálewey stronie / stali cżárni murzynowie straszliwi [podkr. R.Z.]” [SkarŻyw 98], „Tym czasem do onego cżłeká (...) przystapił ieden czarny sprosny murzyn [podkr. R.Z.] / y wytnie mu ćięszki policzek mowiąc” [SkarŻyw 107], „Vźrzał pod gorą bieżąc dziwnego cżłowieká (...). Brudny / cżarny by Murzyn / szpetny/ okopciáły [podkr. R.Z.]" [RejWiz158].

W materiale SL odniesienia przymiotnika czarny do ludzi są również widoczne, por. „Leszek Czarny nazwany, dla włosów tej farby” [Naruszewicz], czarny chrześcijanin, także w znaczeniu negatywnej oceny moralnej 'czarny, brzydki, występny', por. „Ty rażący oczy moje, uchodź najczar- 
niejszy człowieku" [Teat. 2, 73]. Warto dodać, iż można tu zaobserwować rozrost gniazda słowotwórczego przymiotnika. Odnoszące się do człowieka nacechowane negatywnie elementy tego gniazda to: czerń w następujących znaczeniach: 'ludzie czarni', por. „Melanchlaeni, quos nos czerń vocamus, naród u Herodota czarnych ludzi" [Statut Sarnickiego 963], 'pospólstwo, czarni chrześcijanie', por. „Zbuntował czerń albo chłopów ukraińskich” [Steb. 2, 272], 'zbuntowane chłopstwo', por. „Ruszyła się cała wieś na czerń” [Oss.Wyr.], czerniec w ogólności 'człowiek czarny', por. „Czerniec, co z piekła powrocił” [Rey Wiz. 159]. Odnotowano również znaczenia neutralne, ale stylistycznie ograniczone, np. czerniec $\mathrm{w}$ czerni człowiek, ubrany czarno; zakonnik czyli mnich (prawosławny)', ogólnie 'pop, mnich'. Spośród innych derywatów pochodzacych od przymiotnika czarny w SL wymieniono czarnucha, czernucha, zdrob. czarnuszka 'miano co się daje czarnym krowom i kozom'; też w znaczeniu botanicznym czarnucha, czernuszka 'nigella' [SL]. SWil notuje adi. czarny w odniesieniu do człowieka jedynie w kontekście negatywnej cechy moralnej. Wyrażenie czarny człowiek 'Murzyn' zostało udokumentowane w SW.

Pierwsze ślady funkcjonowania jednostki czarny w użyciu rzeczownikowym można dostrzec w dobie średniopolskiej, por. czarny 'czart, diabeł' $z$ cytatem $z$ Pamiętników J.Ch. Paska [SXVII/XVIII], przy czym trzeba powiedzieć, że ani SXVII/XVIII, ani SWil, ani SW nie notuja substantywizowanego przymiotnika czarny w odniesieniu do Murzyna.

W wypadku zaś kolejnego $z$ interesujących nas ekwiwalentów tłumaczeniowych - etnonimu nazywającego mieszkańca Etiopii, warto wskazać na fakt słowotwórczy, zwiazany $z$ użyciem synonimicznych względem siebie przyrostków, tworzących nazwy mieszkańców w dawnej polszczyźnie. Warianty Etyjopczyk // Etyjopianin ${ }^{8}$ odzwierciedlają rywalizację sufiksów -czyk i -anin w obrębie formacji etnonimicznych w okresie średniopolskim, przy czym już w wieku XVI morfem -czyk wzmocnił swoja produktywność kosztem formantu -(j)anin. Proces ten nasilił się w wiekach następnych (XVII-XIX) [zob. Sulisz 1969, 291-319; Zarębski 2003]. Formę Ethiops - nazwa plemienna Etiopów wywodzona jest ze staroegipskiego atioban 'handlarze kadzidłem' lub greckiego Ethiopia 'kraj ciemnych twarzy' (gr. aitho 'palić', ops 'twarz')' - w funkcji indywidualnego określenia identyfikacyjnego notuje SSNO: „Casimirus III rex Hincowi Ethiopi, advocatiam in oppido Bandzyn ... donat" XIV in. [1358] [Matr IV/3 suppl. 194] (por. Aetiops 'Murzin' SMącz) [SSNO t. 3; SEMot t. 4].

Obserwacja ekwiwalentów tłumaczeniowych odnoszących się do mieszkańców Afryki w średniopolskich przekładach NT, danych leksykograficznych, a także ustaleń dotyczących wizerunku osób czarnoskórych utrwalonego w dawnym piśmiennictwie [zob. Niewiara 2000, 149-150] skłania do następujących wniosków. Rzeczownik Murzyn pojawił się w polszczyźnie wraz z pierwszymi tłumaczeniami Biblii, przy

${ }^{8}$ M. Sulisz [1969] nie notuje żadnej z tych form. 
czym początkowo był on - podobnie jak i inne elementy należące do jego gniazda słowotwórczego - neutralny pod względem stylistycznym i emocjonalnym. Jednakże już w XVI wieku, kiedy coraz częściej zaczęto mówić o ludności czarnoskórej, kiedy też niektórzy z podróżujących Polaków mogli nawet zobaczyć człowieka rasy czarnej, zaczyna się kształtować negatywny obraz. Dowodza tego bezsprzecznie źródła słownikowe, gromadzace leksykę historyczna. Ważnym kontekstem dla poruszanych tu kwestii sa obserwacje Aleksandry Niewiary dotyczace obrazu Murzyna $\mathrm{w}$ dawnej literaturze pamiętnikarskiej. W wizerunku tym podkreślano aspekt fizyczny, odnoszacy się do czarnego koloru skóry, i ekonomiczno-społeczny, wiążący się z niska pozycją tej ludności. Zdaniem badaczki stereotypizację Murzyna $z$ dominujaca cechą niższości w drabinie społecznej widać już w pełni w XIX w. [zob. Niewiara 2000, 149-150]. Stereotyp ów znacznie się $z$ czasem pogłębił.

W odniesieniu do analizowanego korpusu nasuwa się istotne spostrzeżenie, że tłumacze okresu średniopolskiego dość swobodnie wybierali ekwiwalent tłumaczeniowy odnoszacy się do czarnoskórych mieszkańców Afryki. Jeden $z$ ważniejszych czynników zewnątrzjęzykowych, który determinuje kształt stylistyczny przekładu biblijnego, jakim jest podstawa tłumaczenia [zob. Bieńkowska 2002, 24-33], nie wpłyną tu na translatorskie wybory. Nie zdeterminował ich także czynnik konfesyjny, gdyż te same odpowiedniki mogły być wykorzystane w tłumaczeniach różnych pod względem wyznaniowym. Jedyna prawidłowość o charakterze stylistyczno-pragmatycznym, która można dostrzec w dystrybucji poszczególnych ekwiwalentów, dotyczy unikania różnych form w bliskim sąsiedztwie. Postępowanie takie pozytywnie wpłynęło na ukształtowanie stylistyczne poszczególnych przekładów. Swobodny wybór jednego ekwiwalentu należącego do pola nazw osób czarnoskórych w pełni natomiast dowodzi, że w początkowej fazie doby średniopolskiej nie były one jeszcze obarczone ładunkiem stylistyczno-emocjonalnym. Sytuacja ta zmieni się w czasach późniejszych.

\section{Bibliografia i skróty}

BB: Biblia to jest Ksiegi starego i Nowego Przymierza. In der Übersetzung des Simon Budny. Nieśwież, Zasław 1571-1572. Herausgegeben von Hans Rothe und Friedrich Scholz. Ksiegi Nowego Przymierza Kto pospolicie Nowym Testamentem zowa $z$ wielka praca y pilnym poprawieniem $z$ Greckiego na Polski ięzyk przettumaczone. Biblia Slavica. Seria II: Polnische Bibeln 1994, Paderborn-München-Wien-Zürich.

BBrz: Biblia święta, to jest księgi Starego i Nowego Zakonu właśnie z żydowskiego, greckiego $i$ łacińskiego nowo na język polski z pilnościa $i$ wiernie wyłożone..., Brześć Litewski 1563.

BG: Biblia Święta. To jest Ksiegi Starego i Nowego Przymierza (...), na polski pilnie i wiernie przetłumaczone, Gdańsk 1632. 
D. Bieńkowska, Polski styl biblijny, Łódź 2002.

BL: Biblia to jest księgi Starego $i$ Nowego zakonu na polski język z pilnościa według łacinskiej Biblii, od Kościoła krześcijańskiego powszechnie przyjętej, nowo wyłożona..., wyd. III, Kraków.

P.Cz. Bosak OP, Postacie Nowego Testamentu. Słownik-konkordancja, Poznań - Pelplin 1996.

BT: Pismo Święte Starego i Nowego Testamentu $w$ przekładzie z języków oryginalnych, oprac. zespół biblistów polskich pod red. benedyktynów tynieckich, Poznań 1965.

BW: Biblia to iest Ksiegi Starego y Nowego Testamentv: wedtvg łacinskiego przekładu starego, $w$ kościele powszechnym przyietego, na polski ięzyk $z$ nowu $z$ pilnościa przełożone, $z$ dokładaniem textv zydowskiego y greckiego y $z$ wykładem katholickim, trudnieyszych mieysc, do obrony wiary swiętey powszechney przeciw kacerztwom tych czasów należacych; przez D. Iakuba Wvyka z Wagrowca, theologa Societatis Iesu, Kraków 1599, http://www. madel.jezuici.pl/biblia/Biblia-Wujka-C.pdf (dostęp: 11.06.2018).

KartSXVII/XVIII: Kartoteka Słownika języka polskiego XVII i 1. połowy XVIII; http:/ / rcin.org.pl/publication/20029 (dostęp: 29.05.2018).

C.S. Keenner, Komentarz historyczno-kulturowy do Nowego Testamentu, redakcja naukowa wydania polskiego K. Bardski, W. Chrostowski, Warszawa 2002.

M. Kossowska, Biblia w języku polskim, t. 1, Poznań 1968.

I. Kwilecka, 2001, Kommentare: Eigennamen [w:] Die Brester Bibel: kulturgeschichtliche und Sprachliche Fragen der Übersetzung [w:] Biblia Slavica, Hrsg. von H. Rothe und F. Scholz, serie II: Polnische Bibeln. Band 2: BresterBibel 1563; Teil 1: Stary Zakon, Teil 2: Nowy Testament, Paderborn, s. 1580-1587 (maszynopis w polskiej wersji językowej s. 155-169).

NA: Novum Testamentum Graece et Latine Textum Graecum post E. et E. Nestle communiter ediderunt B. et. K. Aland..., Stuttgart 1984, Deutsche Bibelgesellschaft; http://www.nestle-aland.com/en/read-na28-online/ (dostęp: 11.06.2018).

A. Niewiara, Wyobrażenia o narodach $w$ pamiętnikach $i$ dziennikach $z$ XVI-XIX wieku, Katowice 2000.

NTB: Nowy Testament znowu przełożony, a na wielu mieyscach za pewnemi dowodami odprzysad przez Simona Budnego ocżyściony, y krotkiemi przypiskami po kraiochob-iaśniony. Przydane też sa na końcu tegoż dostatecżnieysze przypiski, które każdey iakmiarz odmiany przyczyny ukazuia, tłum. S. Budny, Łask 1574; http://www.wbc.poznan.pl/Content/120603/index. djvu (dostęp: 18.06.2018).

NTCz: Nowy Testament, to jest wszystkie pisma Nowego Przymierza z greckiego języka na rzecz polska wiernie $i$ szczerze przełożone..., Raków 1577.

NTM: Nowy Testament zupełny. Z greckiego języka na polski przełożony $i$ wykładem krótkim objaśniony..., Królewiec Pruski 1553, nakładem Jana Seklucjana.

NTSz: Nowy Testament polskim językiem wyłożony według (...) łacińskiego tekstu od Kościoła krześcijańskiego przyjętego..., Kraków 1556, u dziedziców Markusa Szarffenberga.

NTW: Nowy Testament w przekładzie ks. dr. Jakuba Wujka z roku 1593, wstępem i uwagami poprzedził ks. dr W. Smereka, Kraków 1966. 
R. Pietkiewicz, Biblia Polonorum. Historia Biblii w języku polskim, t. 1: Od początku do 1638 roku, Poznań 2016.

SEBań: A. Bańkowski, Etymologiczny słownik języka polskiego, t. 1-2, Warszawa 2000.

SEBor: W. Boryś, Słownik etymologiczny języka polskiego, Kraków 2005.

SEBr: A. Brückner, Słownik etymologiczny języka polskiego, Kraków 1927.

SEMot IV: Słownik etymologiczno-motywacyjny staropolskich nazw osobowych, cz. 3: Odmiejscowe nazwy osobowe, oprac. Z. Kaleta przy współudziale E. Supranowicz i J. Szymowej; cz. 4: Nazwy osobowe pochodzace od etników, oprac. E. Supranowicz, Kraków 1997.

SL: S.B. Linde:, Słownik języka polskiego, wyd. 2, Lwów 1854-1860.

SSNO: W. Taszycki (red.), Słownik staropolskich nazw osobowych, t. I-VI, Wrocław 1965-1983; VII. Suplement, oprac. pod kier. M. Malec, Wrocław 19841987; http://rcin.org.pl/publication/39927 (dostęp: 29.05.2018).

SStp: S. Urbańczyk (red.), Słownik staropolski, t. 1-9, Wrocław-Warszawa-Kraków 1953-1987, t. 10-11, Kraków 1988-2002.

M. Sulisz, Budowa słowotwórcza nazw etnicznych $w$ języku polskim (Formacje $z$ przyrostkiem -'anin, -ak// -'ak, -czyk, -'ec, -ek, -ik//-yk, -in//-yn), „Rozprawy Komisji Językowej Wrocławskiego Towarzystwa Naukowego” 1969, t. VII, s. 287-341.

SW: J. Karłowicz, A.A. Kryński, W. Niedźwiedzki, Słownik języka polskiego, Warszawa 1900-1927.

SWil: A. Zdanowicz (red.), Słownik języka polskiego, Wilno 1861; http://eswil. ijp-pan.krakow.pl/index.php (dostęp: 19.06.2018).

SXVI: Słownik polszczyzny XVI wieku, t. I-IV red. komitet redakcyjny, t. V-XVII red. M.R. Meyenowa, t. XVIII-XXXIV red. F. Pepłowski, t. XXXV-XXXVI red. K. Mrowcewicz, P. Potoniec, Wrocław-Warszawa-Kraków 1966-2012.

SXVII/XVIII: Elektroniczny słownik języka polskiego XVII i XVIII wieku; https:/ / sxvii.pl/ (dostęp: 19.06.2018).

R. Zarębski, Etnonimy $i$ nazwy odetniczne $w$ polskich przekładach Nowego Testamentu, „Onomastica” 2003, t. XLVIII, s. 45-78.

R. Zarębski, Nazwy czarnoskórych mieszkańców Afryki we współczesnych przekładach Nowego Testamentu na tle przemian kulturowych [w druku]. 


\section{Aneks}

\begin{tabular}{|c|c|c|c|c|}
\hline \multirow[b]{2}{*}{ Przekład } & \multirow[b]{2}{*}{$\begin{array}{c}\text { Przynależność } \\
\text { konfesyjna }\end{array}$} & \multicolumn{3}{|c|}{ Lokalizacja } \\
\hline & & 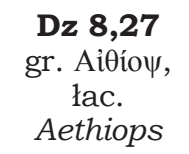 & 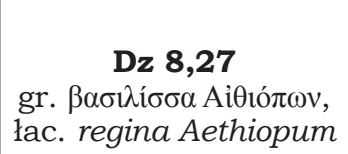 & 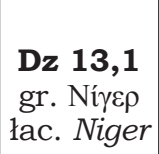 \\
\hline NTM & protestancki & $\begin{array}{l}\text { murzyn } \\
\left({ }^{*} \text { Etiopczyk) }\right.\end{array}$ & królowa Murzyńska & $\begin{array}{l}\text { Niger } \\
\left({ }^{*} \text { czarny }\right)\end{array}$ \\
\hline NTSz & katolicki & murzyn & królowa Murzyńska & czarny \\
\hline BL & katolicki & Murzyn & królowa Murzyńska & czarny \\
\hline BBrz & protestancki & Etiopczyk & królowa etiopska & Czarny \\
\hline NTB & protestancki & murzyn & królowa murzyńska & $\begin{array}{l}\text { Niger } \\
\left({ }^{*} \text { czarny }\right)\end{array}$ \\
\hline BB & protestancki & murzyn & królowa murzyńska & Niger \\
\hline $\mathrm{NTCz}$ & protestancki & Etiopczyk & królowa etiopska & Niger \\
\hline NTW & katolicki & Etiopianin & królowa etiopska & Niger \\
\hline BW & katolicki & Etiopianin & królowa etiopska & Niger \\
\hline BG & protestancki & murzyn & królowa murzyńska & Niger \\
\hline
\end{tabular}




\section{Names of black inhabitants of Africa in old translations of the New Testament}

\section{Summary}

The author analyses translation equivalents of the names referring to black

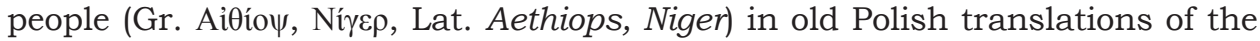
New Testament. He has excerpted translations based on Greek sources as well as on the Latin Vulgate, diversified according to the translation method and religious denomination. The number of the excerpted Polish equivalents (transferred words: 'Niger', adopted words: 'Murzyn' (Negro), and its derivatives, ethnonyms: 'Etiopczyk', 'Etyjopianin' (Ethiopian), native words: 'Czarny' (Black)) have been confronted with the terms accepted in etymological dictionaries and history books. The author concludes that the translators from the Middle Polish period used the translation equivalents referring to black inhabitants of Africa quite freely. The reason for that was that the names 'Murzyn' and 'Czarny' were not burdened with such a stylistic and pragmatic load in the Old Polish language as they are in Modern Polish.

Keywords: translation studies - translations of the New Testament in the $16^{\text {th }}$ and $17^{\text {th }} \mathrm{c}$. - translation rules - stylistic and pragmatic criteria - equivalents of the names of black inhabitants of Africa.

Adj. Monika Czarnecka 